\title{
Colin Feasby
}

\section{Contemporary Issues in Canadian Political}
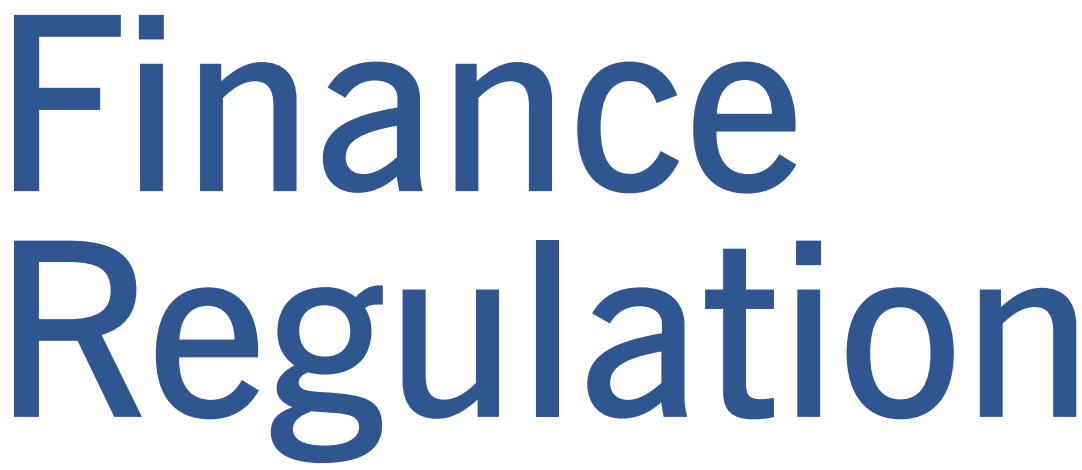

Introduction

Canada shares with New Zealand a heritage of British

constitutional traditions and the Westminster form of

parliamentary government. These common origins make

comparative study of the two countries' experiences

regulating political finance inviting. Canada and New

Zealand, however, differ in important ways which have had

significant impacts on the regulation of political finance. This article outlines the Canadian political finance regime and identifies some contemporary issues that may be of interest to observers from New Zealand.

The article begins with a brief review of the Canadian context, including the electoral system and political finance regulation. Part two concerns the Canadian constitution and its impact on political finance regulation. The development of political finance jurisprudence in Canada through disputes involving third-party spending limits and the differential treatment of small political parties are discussed. The third section considers the impact of amendments to the Canada Elections Act 2000 (CEA) in 2003 and 2006 that introduced contribution limits and quarterly allowances for political parties. Lastly the article discusses ways in which political spending may escape regulation in Canada.
The Canadian context ${ }^{1}$

The Canadian electoral system

Canada is a federation comprised of ten provinces and three territories. The federal parliament is a bicameral legislature comprised of an elected House of Commons and an appointed Senate. The provincial and territorial assemblies are unicameral and comprise elected representatives. All elections to the federal House of Commons and provincial legislatures follow the traditional Westminster form: the candidate receiving the most votes in each electoral district is elected.

Canada is a large country with diverse geography, economy and culture. The most obvious example of this diversity is the majority French-speaking province of Quebec. Throughout much of Canada's history, regional and linguistic-cultural differences were brokered through two large centrist political parties, the Liberal Party and the Progressive Conservative Party. During the second half of the 2oth century a smaller, left-leaning party affiliated with organised labour, the New Democratic Party (NDP), also consistently elected a small number of representatives to the House of Commons.

Canada's longstanding party system broke down in the late 1980 os and early 1990s. The breakdown translated into a fractured House of Commons following the 1993 federal election. The Bloc Québécois (BQ), a separatist party, took most of the seats in Quebec in the 1993 
federal election and formed the official opposition. The Reform Party, a populist and ideologically conservative party based in Western Canada, came third in the election. The NDP finished fourth and the formerly governing Progressive Conservative Party was reduced to a small rump in fifth place. This fiveparty system has now become a fourparty system as a result of the merger of the Reform Party and the Progressive Conservative Party. Once again there are two large parties: the Liberal Party and the Conservative Party. However, in the period since 2004 neither has been able to form a majority government. The Liberals and then the Conservatives have ruled in minority governments without any formal coalition with the NDP or the $\mathrm{BQ}$. The result has been frequent elections and more aggressive partisan tactics than Canadians have been accustomed to over the past century.

\section{Framework of political finance regulation}

The CEA political finance regime is based on election expense controls and disclosure. However, political party and candidate expenses are regulated only during an election period. An 'election period' is defined by the CEA as being 'the period beginning with the issue of the writ and ending on polling day'. An expense includes 'any cost incurred, or non-monetary contribution received, by a registered party or candidate ... used to directly promote or oppose a registered party, its leader, or candidate during an election'. Outside an election period there are no limits on the expenditures of political parties and candidates. The election expense limits for political parties and candidates are determined by a statutory formula that is adjusted annually for inflation. Candidates and political parties must file financial returns with the chief electoral officer following an election.

Contributions to political parties, candidates and electoral district associations have been regulated by way of mandatory disclosure since 1974. Contributions are defined by the CEA broadly to include monetary and non-monetary contributions and also a candidate's own funds used for election expenses. The regulation of contributions captures money transferred from the private domain to the political domain. A transfer of money between entities within the political domain - candidates, electoral district associations and registered political parties - is not a 'contribution'. Contributions may not be made indirectly to conceal the identity of the contributor. The name and address of all individuals making contributions of over $\$ 200$ must be disclosed by the candidate or political party receiving the contribution.

The existing contribution disclosure approach was reinforced by the introduction of contribution limits in amendments to the CEA in 2003. ${ }^{2}$ Contributions by corporations and election expenses. A political party which receives $2 \%$ of the national popular vote or at least $5 \%$ of the votes in the electoral districts in which it endorsed candidates is entitled to be reimbursed $50 \%$ of its election expenses. Political parties which qualify for reimbursement of election expenses also qualify for a quarterly allowance determined by the number of votes cast for the party in the last general election.

\section{The Canadian constitution and political finance \\ Charter review}

Political finance regulation exists in the shadow of the Canadian Charter of Rights and Freedoms. ${ }^{5}$ The charter is a constitutional bill of rights which sets out

\section{There are three forms of public funding in the Canadian political finance regime: tax deductions for contributors; reimbursement of election expenses for candidates and political parties; and political party allowances.}

trade unions were prohibited, subject to a limited exception for contributions of up to $\$ 1,000$ to candidates and constituency associations. Individual contributions were limited to $\$ 5,000$ adjusted annually for inflation to 'each registered political party and its registered associations, nomination contestants, and candidates'. Further amendments to the CEA contained in the 2006 Federal Accountability Act reduced individual contribution limits to $\$ 1,000$ (adjusted annually for inflation) and extinguished the right of corporations and trade unions to contribute even $\$ 1,000$ to candidates and constituency associations. ${ }^{3}$

There are three forms of public funding in the Canadian political finance regime: tax deductions for contributors; reimbursement of election expenses for candidates and political parties; and political party allowances. ${ }^{4} \mathrm{~A}$ candidate who receives $10 \%$ of the vote is entitled to be reimbursed $60 \%$ of his or her rights that limit the power of the state. Laws that contravene the charter may be declared to be invalid and of no force or effect. As a result, courts play a hand in shaping political finance regulation through case law. The implicit threat of litigation also shapes choices made by parliament in regulating political finance. Political finance regulation engages three main aspects of the charter: freedom of expression (s.2(b)), the right to vote (s.3) and the right to equality (s.15).

The first element of charter analysis is consideration of whether the challenged legislative provision violates a protected right. The plaintiff bears the burden of establishing that a charter right has been infringed. The charter, unlike the US Bill of Rights, contains an explicit limiting principle. Section 1 of the charter provides that rights guaranteed are subject 'to such reasonable limits prescribed by law as can be demonstrably justified in a free and democratic society. ${ }^{6}$ Once a 
plaintiff proves the violation of a right, the state bears the burden of proving that the limit on the right is reasonable and justified. The justification test is comprised of two main aspects. First, the court must determine whether the legislation addresses a pressing and substantial objective. Second, the court conservative interest group the National Citizens' Coalition (Geddis, 2004; Feasby, 2005). Harper asserted that third-party spending limits violated section 2 (b) of the charter by unreasonably infringing upon freedom of expression.

The third-party spending limits applied to communications which

\section{When third-party spending limits were adopted in 2000 , third parties were also required to file a return with Elections Canada disclosing details of their contributions and expenditures.}

must determine whether legislative means are proportional to the objective. The second part of the test considers: (1) whether the means and objective are rationally connected; (2) whether the means minimally impair the right in question; and (3) the salutary and deleterious effects of the legislation.?

Most charter challenges to political finance regulation have taken place at the margins of the political finance regime. There have been repeated challenges to the regulation of third-party (or 'parallel campaigner') spending and to the preferential treatment of political parties and candidates in respect of public funding. The core elements of the political finance regime that apply to the major political parties have not been challenged. Indeed, the courts have proceeded on the implicit assumption that financial disclosure and spending limits on candidates and political parties are constitutional.

\section{Third parties}

Third-party expenditures were first regulated in 1974 and have been a source of controversy ever since. After being declared unconstitutional in the mid1990s, third-party spending limits were adopted again in amendments to the CEA in 2000. The third-party spending limits were promptly challenged by Stephen Harper, now Canada's prime minister, who was the leader of the 'promote or oppose the election of one or more candidates in a given electoral district, including by (a) naming them; (b) showing their likeness; (c) identifying them by their respective political affiliations; or (d) taking a position on an issue with which they are particularly associated'. Harper contended that the limits were either vague or overly broad and, as a result, unduly infringed upon freedom of expression. He further asserted that there was no evidence to support the government's claim that third-party spending was a threat to the integrity of elections. The financial limits, Harper also contended, were unreasonably low and did not permit effective campaigning.
The spending limits permit third parties to spend $\$ 3,000$ per electoral district to a maximum of $\$ 150,000$ nationally.

The Supreme Court of Canada accepted that the purpose of third-party spending limits was to promote equality and that this purpose was pressing and substantial. The court dismissed the claim that there was no evidence to support the existence of a pressing and substantial objective, holding that parliament had acted based on a reasoned apprehension of harm and that a relaxed evidential standard applied given the importance of the objective. It went on to reject Harper's argument that the third-party limits were vague or overly broad. The court acknowledged the breadth of the restrictions, but found that such breadth was justifiable in the circumstances.

The court split over whether the limits in question were too low. The majority deferred to parliament and accepted that the limits allowed for a modest informational campaign. The minority concluded that 'the limits imposed on citizens amount to a virtual ban on their participation in political debate during the election period'. ${ }^{8}$ The disagreement between the minority and the majority stemmed, in part, from the poor evidential record before the court. A challenge to British Columbia's restrictions on third-party spending, which are nearly identical to the federal limits, has been heard by the BC Supreme Court and is pending before the BC Court

Table 1: Third-party expenditures in the 2000, 2004, 2006 and 2008 general elections $^{10}$

\begin{tabular}{|lrrrr|}
\hline & \multicolumn{4}{c}{ Number of registered third parties } \\
\hline Expenditure levels & 2000 & 2004 & 2006 & 2008 \\
\hline No return & 0 & 4 & 7 & 4 \\
\hline$\$ 0.00$ & 6 & 12 & 7 & 3 \\
\hline$\$ 0.01-\$ 4,999.99$ & 30 & 31 & 44 & 32 \\
\hline$\$ 5,000.00-\$ 9,999.99$ & 8 & 4 & 2 & 4 \\
\hline$\$ 10,000.00-\$ 24,999.99$ & 2 & 4 & 5 & 7 \\
\hline$\$ 25,000.00-\$ 49,999.99$ & 1 & 3 & 8 & 5 \\
\hline$\$ 50,000.00-\$ 99,999.99$ & 1 & 4 & 5 & 4 \\
\hline$\$ 100,000.00$ and over & 2 & 1 & 2 & 5 \\
\hline Total number & 50 & 63 & 80 & 64 \\
\hline Total expenditures & $\$ 573,854.20$ & $\$ 720,227.93$ & $\$ 1,067,680.75$ & $\$ 1,430,579.14$ \\
\hline Average expenditure & $\$ 11,477.08$ & $\$ 12,207.25$ & $\$ 14,625.76$ & $\$ 23,842.99$ \\
\hline
\end{tabular}


of Appeal. ${ }^{9}$ This case offers the possibility of revisiting the debate over the type of campaigns that can be conducted within the third-party limits with the benefit of a more complete evidential record which includes expert testimony.

When third-party spending limits were adopted in 2000, third parties were also required to file a return with Elections Canada disclosing details of their contributions and expenditures. Any future litigation over third-party spending limits will benefit from the data that has been gathered by Elections Canada from third-party election expense returns. Table 1 indicates that third-party spending is increasing; however, it is also clear that third-party spending remains negligible when compared to political party and candidate spending. For example, the Conservative Party together with its candidates spent $\$ 37,235,930$ in the 2006 federal election. Furthermore, few third parties spend the maximum allowed under the limits, which suggests that there would be little risk in raising them.

\section{Small political parties}

The Canadian political finance system employs a series of thresholds, outlined above, to ensure that public funding flows only to 'serious' candidates and political parties. Prior to 2003 political parties were required to field 50 candidates to become a 'registered political party' with Elections Canada. Registered political parties receive a number of benefits, including candidate-political party affiliation identified on the ballot and the right to issue tax receipts to donors. The ability to issue tax receipts enhances political parties' fundraising capacity, as donors are more likely to contribute if they receive a benefit in return in the form of reduced taxes.

Miguel Figueroa, leader of the Canadian Communist Party, challenged the 50-candidate threshold on the grounds that it violated the right to vote and to run for office protected by section 3 of the charter. ${ }^{11}$ Figueroa contended that the threshold created a systemic bias against small political parties and in favour of large political parties. The systemic bias prevented small parties from communicating their messages to voters and playing a meaningful role in the electoral process. The government response was that the 50-candidate threshold and the systemic bias in favour of large parties was justified because regulations should enhance the ability to communicate of those parties which have a reasonable chance of forming the government.

The majority of the Supreme Court of Canada disagreed. The court held that deposits in Ontario's Election Act to be unconstitutional. ${ }^{16}$ The court applied Figueroa and concluded that the benefit of the threshold was 'overcome by the deleterious effects of diminishing the capacity of [small] political parties to present their ideas and opinions.' ${ }^{17}$ The Supreme Court of Canada may have to once again consider the rights of small political parties in order to give clear guidance to the lower courts.

\section{Prior to 2003 political parties were required to field 50 candidates to become a 'registered political party' with Elections Canada.}

'participation in the electoral process has an intrinsic value independent of its impact upon the actual outcome of elections.' ${ }^{12}$ Justice Iacobucci went on to observe that 'the ability of a political party to make a valuable contribution to the electoral process is not dependent on its capacity to offer the electorate a genuine "government option". ${ }^{13}$ The court concluded that "legislation that exacerbates a pre-existing disparity in the capacity of the various political parties to communicate their positions to the general public is inconsistent with s.3.'. ${ }^{14}$ As a result, the court held that the 50-candidate threshold was unconstitutional.

Case law following Figueroa has been divided. The Ontario Court of Appeal heard a challenge to the thresholds political parties must meet to qualify for election expense reimbursement and allowances. ${ }^{15}$ The small political parties that brought the challenge took the position that the Supreme Court's decision in Figueroa meant that thresholds to qualify for public funding must be unconstitutional. The Ontario Court of Appeal agreed that the thresholds violated section 3 of the charter, but held that infringement was justified because thresholds were required to maintain public confidence in the electoral process. At about the same time, the Ontario Superior Court of Justice reached a contrary result, finding a threshold for the refund of candidate

\section{Public funding and contribution limits}

Prior to the 1993 breakdown of the duopoly that controlled Canadian politics for most of the 2oth century, the Liberal Party and Progressive Conservative Party raised similar amounts of political funds. Both parties were dependent on corporate donations. The NDP, by contrast, received fewer corporate contributions and instead relied upon financial support from trade unions. The financial equilibrium between the Liberal Party and the Progressive Conservative Party, together with the similar sources of funding, meant that there was little partisan advantage to be gained from changing the fundraising rules.

The Liberal Party dominated fundraising in the fragmented party system that lasted from 1993 to 2000 . The Liberal Party was particularly successful at raising corporate funds, as it was the only political party that could plausibly form the government. During the 1993-2000 period the populist and ideologically conservative Reform Party established an effective grassroots fundraising system. After 2000, the Reform Party's heirs, the Canadian Alliance, and, later, the Conservative Party built upon this fundraising foundation by adopting direct and targeted advertising and other strategies imported from the United States to maximise the number of contributors and contributions.

Contribution limits were adopted by 
the governing Liberal Party in 2003 as part of an effort to rehabilitate the party's image following the 'sponsorship scandal', in which advertising agencies associated with the Liberal Party were used as conduits for government sponsorship of events in Quebec. Even though there was no proof that any of the sponsorship funds returned to the Liberal Party through political contributions, political finance reform including contributions was expedient in the circumstances.

The contribution limits had greater effect on the Liberal Party than on the Conservative Party (Flanagan and Coletto, 2010). The effects of contribution limits were not lost on the Conservative Party when it took power after the election in 2006. One of the reforms it implemented in its Federal Accountability Act 2006 was a reduction in individual contribution limits to $\$ 1,000$ and a prohibition on corporate and union contributions.

Table 2 shows the persistent fundraising advantage enjoyed by the Conservative Party since contribution limits went into effect at the beginning of 2004. The Liberal Party has identified the need to develop a more grassroots approach to fundraising, but has been unable to match the success of the Conservative Party. As the contribution limit system enters its seventh year, the Conservative Party retains a comfortable fundraising advantage over the Liberal Party and, indeed, over all of the opposition parties combined.

Some prominent Liberals, including Liberal Party president Stephen LeDrew, foresaw that contribution limits would damage the Liberal Party's dominant financial position. LeDrew decried the reforms as 'dumber than a bag of hammers' (Gray, 2006). To mitigate the anticipated impact of the contribution limits, public funding of political parties through allowances paid quarterly was introduced. Funding is determined according to a per vote rate based on votes received by each political party in the prior election. The per vote funding amount was set at a level that was intended to replace the funds that would be lost by political parties by reason of the contribution limits.

The allowances mitigated the loss of corporate contributions and large contributions from individuals lost by the Liberal Party. For the Conservative Party, which lost comparatively little as a result of the contribution limits, the allowances were mostly additional funding rather than replacement funding. Success in private fundraising together with public funding has resulted in the Conservative Party having far greater financial resources

Table 2: Contributions to major political parties 2004-09

\begin{tabular}{lrrrrrr} 
Party & 2004 & 2005 & 2006 & 2007 & 2008 & $\mathbf{2 0 0 9 * 1 8}$ \\
BQ & $\$ 858,746$ & $\$ 734,729$ & $\$ 529,513$ & $\$ 429,971$ & $\$ 713,085$ & $\$ 621,126$ \\
\hline Cons. & $\$ 10,949,559$ & $\$ 17,847,451$ & $\$ 18,641,306$ & $\$ 16,983,630$ & $\$ 21,179,483$ & $\$ 17,707,846$ \\
\hline Lib. & $\$ 4,719,388$ & $\$ 8,344,162$ & $\$ 9,063,126.36$ & $\$ 4,471,903$ & $\$ 5,811,492$ & $\$ 9,564,677$ \\
NDP & $\$ 5,194,170$ & $\$ 5,120,827$ & $\$ 3,972,762.57$ & $\$ 3,959,451$ & $\$ 5,412,940$ & $\$ 4,035,492$
\end{tabular}

*2009 data based on quarterly returns, as not all annual returns have been posted by Elections Canada.

Table 3: Annual allowances paid to major political parties 2004-09

\begin{tabular}{lrrrrrr} 
Party & 2004 & 2005 & 2006 & 2007 & 2008 & 2009 \\
\hline BQ & $\$ 2,733,868$ & $\$ 3,064,864$ & $\$ 2,950,984$ & $\$ 2,953,218$ & $\$ 3,017,092$ & $\$ 2,742,215$ \\
\hline Con. & $\$ 7,913,512$ & $\$ 7,331,172$ & $\$ 9,388,357$ & $\$ 10,218,123$ & $\$ 10,439,132$ & $\$ 10,351,071$ \\
\hline Lib. & $\$ 9,141,408$ & $\$ 9,087,333$ & $\$ 8,572,965$ & $\$ 8,517,049$ & $\$ 8,701,263$ & $\$ 7,219,593$ \\
\hline NDP & $\$ 2,883,919$ & $\$ 3,879,817$ & $\$ 4,611,140$ & $\$ 4,923,795$ & $\$ 5,030,293$ & $\$ 4,998,192$
\end{tabular}

Table 4: Political party spending limits in recent elections

\begin{tabular}{lrrr} 
Party & 2004 & 2006 & 2008 \\
\hline BQ & $\$ 4,591,747.38$ & $\$ 4,676,676.52$ & $\$ 5,066,811.35$ \\
\hline Con. & $\$ 17,593,925.32$ & $\$ 18,278,278.64$ & $\$ 19,999,230.62$ \\
Lib. & $\$ 17,593,925.32$ & $\$ 18,278,278.64$ & $\$ 20,014,302.76$ \\
\hline NDP & $\$ 17,593,925.32$ & $\$ 18,278,278.64$ & $\$ 20,063,430.10$
\end{tabular}

than any political party had prior to the adoption of contribution limits and allowances. Table 3 shows the annual allowances paid to political parties since 2004.

The Conservative Party's financial advantage has had an impact on the conduct of politics since 2006. Since 2006 the Conservative Party has governed twice as a minority government. The funding advantage enjoyed by the party has allowed it to govern with more authority than normal in a minority situation. The opposition parties have been reluctant to bring down these minority governments because the Conservative Party has been the only political party that has had the financial wherewithal to comfortably fight an election. As a result, there have been instances where opposition parties have threatened to bring down the government only to relent and compromise, in part because of financial considerations.

The Conservative Party also provoked a crisis over the budget in 2008 by threatening to eliminate the quarterly allowances paid to political parties. The removal of public funding would damage the opposition parties more than the Conservative Party. The threat to funding was one of the few things that has galvanised the opposition parties and caused them to make a convincing threat to defeat the government. The Conservative Party withdrew its proposal.

\section{Spending limits}

\section{Spending outside election periods}

Canadian political parties have always spent some money in the days and weeks immediately prior to the election period. Until recently, however, parties did nothave enough money to engage in significant pre-writ electioneering. As discussed in the previous part of this article, all of this changed in 2004. Since then, the Conservative Party has had the financial resources to engage in extensive pre-writ electioneering. This is demonstrated by a comparison of Conservative Party income from contributions and allowances set out in Tables 2 and 3 with spending limits in recent elections set out in Table 4 . When comparing the tables, it should be noted that political parties are reimbursed 50\% of their election expenditures. 
The competitive partisan dynamic created by three successive minority governments, together with the financial disparity between the parties has resulted in expanded use of political advertising. The Conservative Party has not been content to merely ramp up its election campaign in the weeks and months immediately prior to the election period; it has also engaged in strategic advertising campaigns when no election campaign was imminent. The most famous examples were the negative advertisements aimed at Stephane Dion when he became leader of the Liberal Party in 2006 and at Michael Ignatieff after he became leader of the Liberal Party in late 2008.

The Conservative Party's use of advertising to influence political images and debates outside election periods and increased use of pre-writ election advertising has forced the other political parties to respond in kind. Despite their comparatively weak financial positions, both the Liberal Party and NDP have engaged in advertising to compete with and respond to the Conservative Party. The inability of the Liberal Party to compete in an advertising arms race provoked Dennis Dawson, a Liberal senator, to introduce a bill in the Senate to control some pre-writ election spending by political parties. The bill would include within the definition of 'election expense' any cost 'incurred in the three month period prior to the election period'. The bill, being a private member's bill originating in the Senate, stands little chance of becoming law and is best understood as a protest against the effects of Conservative Party financial dominance.

An interesting twist on pre-writ regulation of expenditures is found in British Columbia's Election Act. The 2005 provincial election in British Columbia was marked by increases in third-party spending. As a result, BC adopted thirdparty spending limits which mirrored the federal limits but extended into the 60day period before the call of an election. The third-party limits were challenged by the BC Teachers Federation. ${ }^{19}$ The $\mathrm{BC}$ government attempted to justify the extension of the third-party limits into the pre-writ period on the grounds that it was necessary to stop third parties

from circumventing spending limits that apply to the election period. The BC Supreme Court did not find this position compelling. The court held that regulation of third-party spending outside the election period could not be justified as it was not proximate enough to an election and, as a result, did not pose as great a threat to the integrity of an election. The court further held that the extension of third-party limits outside the election period was problematic because it prevented full participation in public debate while the legislature was in session.

\section{Advertisements that promote a political party necessarily provide a benefit to a candidate affiliated with that political party whether or not the candidate's name is used.}

\section{Expenditure limit arbitrage}

A second way in which the Conservative Party has used its financial advantage is what I have termed 'expenditure limit arbitrage'. Under the Canadian political finance system, political party spending limits are separate from candidate spending limits. The major political parties typically spend close to the maximum permitted. However, candidates of the major political parties in uncompetitive districts often do not spend the maximum allowed. The unused spending capacity of candidates represents an opportunity for a political party with more funds than it can use under its spending limits because there are no limits on transfers of funds between political parties and affiliated candidates.

The method devised by the Conservative Party to exploit the unused spending capacity of candidates was described by the Federal Court in Campbell v. Canada (Chief Electoral Officer) in the following terms:

The evidence shows that the Party did in fact finance candidates' contributions using the following scheme: first, the Fund issued an invoice to the official agent. Simultaneously, the official agent completed a wire transfer form instructing the same amount indicated in the invoice to be transferred from the campaign to the Fund. This wire transfer form was signed and sent back to the Fund, who filled in any missing information. The Fund then prepared a second wire transfer, directing the same amount of money to be transferred from the Fund to the candidate. Finally, after the transfer from the Fund was completed, the wire transfer form completed by the official agent was sent to the bank to have the money paid right back.
Indeed, during the 2006 election, the Fund transferred some 1.2 million dollars to the 67 local campaigns participating in the RMB program. The totality of this amount was returned to the Fund by way of these 'in and out' transfers with each participating candidates. $^{20}$

An investigation as to whether the Conservative Party exceeded its spending limit is ongoing, but no charges have been laid. The 'in and out' transactions, however, came under judicial scrutiny in Campbell as a result of Elections Canada's denial of election expense reimbursement claims submitted by candidates who participated in the 'in and out' transactions. Despite these concerns, it is hard to conclude that arbitrage between political party and candidate spending limits is illegal. Advertisements that promote a political party necessarily provide a benefit to a candidate affiliated with that political party whether or not the candidate's name is used. Indeed, to insist upon the direct promotion of a candidate would be inconsistent with the broad approach used to defining 'election advertising' in the CEA.

The Federal Court in Campbell was not asked to determine whether the 
Conservative Party exceeded its spending limits. Moreover, the court overturned the chief electoral officer's decision to deny candidates' election expense reimbursement claims. Based on this decision, it appears that if Elections Canada concludes that 'in and out' transactions should be stopped, an amendment to the CEA will be required.

\section{Conclusion}

Political finance has become increasingly important to the practice of politics in Canada in recent years. More money is available to participants in the political process as a result of increased public funding and it is being deployed in more aggressive and creative ways than in the past. At the same time, political finance has become increasingly subject to judicial scrutiny. Small political parties and third parties have launched repeated constitutional challenges to the political finance regime and Elections Canada has taken more enforcement actions. The Canadian political finance landscape, though more contested and dynamic than that found in Australia, the United
Kingdom or New Zealand, remains quiescent compared to the United States.

The Canadian experience is a cautionary tale for New Zealand as it embarks on reform of its political finance regime. The Canadian reforms of 2003 and 2006 show that ostensibly neutral changes to a political finance regime can have a significant impact on the practice of politics and the balance between political parties. Canadian politics today exist in a state of persistent quasi-campaign. This condition is a result of recurring minority governments, but it is also facilitated and exacerbated by increased public funding and the imbalance in funding amongst the major political parties. New Zealand should be cautious before adopting any changes to its political finance legislation. In particular, even in the absence of any constitutional standards, the differential impact of legislation on political parties should be considered.

\footnotetext{
1 Parts of this section are adapted from Feasby, 2010. For a more detailed discussion, see Feasby, 2007.

2 An Act to amend the CEA and the Income Tax Act (political financing), SC 2003, c. 19.

SC 2006, c.9.

4 The reservation and allocation of free and discounted time
}

for political broadcasts is akin to political funding. However, political broadcasting is beyond the scope of this article. For a discussion of the history of the regulation of political broadcasting in Canada see LaCalamita, 1984. For a discussion of constitutional issues related to the regulation of political broadcasting, see Feasby, 2006.

5 Part I of the Constitution Act 1982, being schedule B to the Canada Act 1982 (UK), 1982, c.11 (the 'Charter').

6 This aspect of the charter resembles the European Convention for the Protection of Human Rights and Fundamental Freedoms (4 November 1950), 213 UNTS 221. The New Zealand Bill of Rights Act 1990, s.5 also contains a justified limitations provision that was explicitly modeled on the Canadian charter.

7 R. v Oakes, [1986] 1 SCR 153 and Dagenais v Canadian Broadcasting Corporation, [1994] 3 SCR 835.

8 Harper v Canada (Attorney General), [2004] 1 SCR 827 at [35] per McLachlin CJ.

9 British Columbia Teachers' Federation v British Columbia (Attorney General), 2009 BCSC 436.

10 The data for 2000 is compromised by the fact that midcampaign an injunction was issued by the Alberta Court of Queen's Bench suspending the rules applicable to third parties and then reinstated by the Supreme Court of Canada. 'Average expenditure' figures do not include third parties with no return filed.

11 Figueroa v Canada (Attorney General), [2003] 1 SCR 912.

12 Ibid. at [29].

13 Ibid. at [39].

14 Ibid. at [54].

15 Longley v Canada (Attorney General) (2007), 288 D.L.R. (4th) 599 (Ont. C.A.).

16 DeJong v Ontario (Attorney General) (2007), 287 D.L.R. (4th) 90 (Ont. Sup. Ct.).

17 Ibid. at [79].

182009 data based on quarterly returns as not all annual returns have been posted by Elections Canada.

19 British Columbia Teachers' Federation v. British Columbia (Attorney General), 2009 BCSC 436.

20 Campbell v Canada (Chief Electoral Officer), 2010 FC 43 at[38]-[39].

\section{References}

Feasby, C. (2005) 'Freedom of expression and the law of the democratic process', Supreme Court Law Review (2d), 29

Feasby, C. (2006) 'The Supreme Court of Canada's political theory and the constitutionality of the political finance regime', in K. Ewing and S. Issacharoff (eds), Party Funding and Campaign Financing in International Perspective, Oxford: Hart Publishing

Feasby, C. (2007) 'Constitutional questions about Canada's new political finance regime', Osgoode Hall Law Journal, 45 (513), pp.519-21

Feasby, C. (2010) 'Canadian political finance regulation and jurisprudence', in K. Ewing, J. Tham and J. Rowbottom (eds), The Funding of Political Parties, London: Routledge (forthcoming)
Flanagan, T. and D. Coletto (2010) 'Replacing allowances for Canada's political parties?', University of Calgary SPP briefing papers, pp.3-4, http://www.policyschool.ucalgary.ca/publications

Geddis, A. (2004) 'Liberté, egalité, argent: third party election spending and the charter', Alberta Law Review, 42

Gray, J. (2006) 'Reality check', CBC News Online, 13 June

LaCalamita, J. (1984) 'The equitable campaign: party political broadcasting regulation in Canada', Osgoode Hall Law Journal, 22 